\title{
Socioeconomic Inequalities in Food Consumption: A Cross-Sectional Study in Portuguese Adults
}

\author{
Ana Rita Velhinho ${ }^{a} \quad$ Julian Perelman ${ }^{a, b}$ \\ ${ }^{a}$ NOVA National School of Public Health, Universidade NOVA de Lisboa, Lisbon, Portugal; ${ }^{b}$ NOVA National School of \\ Public Health, Public Health Research Centre, Universidade NOVA de Lisboa, Lisbon, Portugal
}

\section{Keywords}

Diet · Socioeconomic status · Portugal · Adults

\begin{abstract}
Background: Food is a major determinant of chronic noncommunicable diseases. Because of this, social inequalities in food consumption will likely produce social inequalities in disease and life expectancy. Objectives: This study analyses the social inequalities in food consumption in Portugal and whether they differ between men and women and between younger and older people. Methods: Following a cross-sectional observational study, we analyzed data from 11,085 individuals aged 25-64 years who participated in the $2014 \mathrm{Na}$ tional Health Interview Survey (NHIS). Logistic regression models were used to measure the association between socioeconomic conditions, i.e., education and income, and food consumption. The analysis was then stratified by sex and age. Results: A positive gradient for income and education was observed in the consumption of fish, cakes, natural juices, and dairy products. The consumption of legumes and soft drinks was inversely related to income and education. A socioeconomic gradient for fruits and vegetables was observed only among women and older people. Worse-off
\end{abstract}

people consumed less soup, and underprivileged women consumed fewer fast-food products. Conclusion: The food consumption patterns of Portuguese adults are related to their socioeconomic condition, with few variations across demographic categories.

(c) 2021 The Author(s), Published by S. Karger AG, Base on behalf of NOVA National School of Public Health

\section{Desigualdades socioeconómicas no consumo alimentar: um estudo transversal em adultos portugueses}

\section{Palavras Chave \\ Alimentação · Estatuto socioeconómico · Portugal · Adultos}

\section{Resumo \\ Introdução: A alimentação desempenha um importante papel na prevenção de doenças crónicas não transmis- síveis. Desta maneira, desigualdades sociais em consumo alimentar poderão contribuir para desigualdades sociais na doença e esperança de vida. Objetivo: O presente es-}

karger@karger.com www.karger.com/pjp

Karger $\stackrel{\text { ' }}{5}$

BOPEN ACCESS (c) 2021 The Author(s) Published by S. Karger AG, Basel on behalf of NOVA National School of Public Health

This is an Open Access article licensed under the Creative Common Attribution-NonCommercial-4.0 International License (CC BY-NC) (http://www.karger.com/Services/OpenAccessLicense), applicable to the online version of the article only. Usage and distribution for commercial purposes requires written permission.
Correspondence to:

Julian Perelman, jperelman@ensp.unl.pt 
tudo teve como objetivo analisar a existência de desigualdades sociais no consumo alimentar em Portugal, e se as mesmas diferem entre homens e mulheres, e entre pessoas mais jovens e mais velhas. Metodologia: Seguindo um desenho de estudo observacional transversal, foram analisados dados de 11.085 indivíduos, com idades compreendidas entre os 25 e os 64 anos, participantes do Inquérito Nacional de Saúde 2014. Foram aplicados modelos de regressão logística para medir a associação entre as variáveis socioeconómicas, nomeadamente educação e rendimento, e o consumo alimentar. A análise foi estratificada por sexo e idade. Resultados: Um gradiente positivo foi observado, em função da educação e do rendimento, no consumo de peixe, bolos, chocolate e sobremesas, sumos naturais e produtos lácteos. Pelo contrário, observámos um gradiente inverso no de leguminosas e refrigerantes. O gradiente socioeconómico observado no consumo de frutas e legumes apenas foi observado nas mulheres e pessoas mais velhas. Os menos privilegiados consomem menos sopa, e as mulheres menos privilegiadas menos fast food. Conclusão: Os padrões de consumo alimentar dos adultos portugueses relacionam-se com a condição socioeconómica, com poucas variações entre grupos demográficos.

(C) 2021 The Author(s), Published by S. Karger AG, Basel on behalf of NOVA National School of Public Health

\section{Introduction}

Noncommunicable chronic diseases represent an epidemiological, social, and economic challenge, both nationally and internationally. They are currently the leading cause of death worldwide [1]. In addition to the global epidemiological burden, its distribution in the population is unequal, being strongly influenced by socioeconomic factors [2]. Indeed, social inequalities in cancer and cardiovascular disease and their determinants are observed in all European countries [3], including Portugal [4].

These social health inequalities occur not only in the incidence of certain chronic diseases but also in their related risk factors, such as obesity, which depends on food consumption [3]. Thus, food may be one of the factors responsible for social inequalities in health $[5,6]$, since food consumption is also unevenly distributed $[7,8]$.

In Portugal, inadequate dietary habits lead the list of main risk factors that take more years of healthy life from the population. It is estimated that $6-8 \%$ of disabilityadjusted life years were attributable to dietary risks at the national level in 2019 [9]. Globally, adherence to the
Mediterranean dietary pattern was estimated at only $18 \%$ in the National Food, Nutrition and Physical Activity Survey 2015-2016, and it was lower among women, younger people, and those suffering from food insecurity [10]. Despite the evidence on health inequalities in Portugal and the weight of diet in the years of healthy life lost, the evidence on inequalities in food consumption among the Portuguese adult population is scarce. A study published in 2004 pointed to similar patterns of consumption among social groups [11], but this situation may have been altered under the effect of generational changes and economic crisis [12]. Another study pointed to inequalities in food, of poorer quality in socially disadvantaged people, but focused only on the consumption of fruits and vegetables [13]. More recently, a study pointed to socioeconomic discrepancies in food consumption in Portugal but focusing specifically on children and adolescents [14].

This study analyzes the education- and income-related socioeconomic inequalities in the food consumption patterns of Portuguese adults, focusing on various types of consumption. Education and income are the most used indicators for the study of socioeconomic inequalities in health, not only due to their availability in most health surveys but also because their causal link to health has been widely demonstrated [15]. Education is related to health literacy, better jobs, earnings, and social position, with psychosocial consequences. Income allows better access to care, living conditions, and security. In addition, the literature shows that the consumption of vegetables, fruit, fish, and dairy products is more common among women, while meat consumption is more common among men. In general, women are more likely to adopt protective behaviors and health promoters than men [16]. Thus, we further assess whether, because of these gender differences, socioeconomic inequalities in food consumption occur equally among men and women.

\section{Materials and Methods}

We used data from the National Health Interview Survey (NHIS) conducted in 2014. The NHIS 2014 addressed approximately 22,000 dwellings in mainland Portugal and sought to characterize the resident population aged over 15 years regarding health status, health care, and lifestyle determinants of health, such as smoking habits, food consumption, and physical activity practice. The data were collected through a sample household survey, through the internet, and in face-to-face interviews from September to December 2014. The selection of the dwellings followed a multistage and sampling method stratified by regions, and in each selected dwelling only 1 resident served as the respondent (more details about the survey methods, including ethical issues, can be found elsewhere [17]). 
Table 1. Sample characterization

\begin{tabular}{lcr}
\hline & Women, $n(\%)$ & Men, $n(\%)$ \\
\hline Age group (years) & & \\
25-34 & $1,024(16.9)$ & $819(16.3)$ \\
$35-44$ & $1,696(28.0)$ & $1,492(29.6)$ \\
$45-54$ & $1,629(26.9)$ & $1,394(27.7)$ \\
$55-64$ & $1,699(28.1)$ & $1,332(26.4)$ \\
Education level & & \\
$\quad$ Preschool or none & $210(3.5)$ & $194(3.9)$ \\
Basic education & $3,151(52.7)$ & $3,046(61.3)$ \\
Secondary education & $1,163(19.4)$ & $909(18.3)$ \\
College education & $1,456(24.3)$ & $819(16.5)$ \\
\hline
\end{tabular}

We restricted the sample to individuals aged 25-64 years $(n=$ $11,085)$. This age range was established because, until the age of 25 years, individuals may not have completed their academic training [18] and because the NHIS does not include institutionalized elderly people, which could result in bias. In addition, the analysis of data referring to the elderly population would need to be different, since the income variable is a weak indicator for this population. It should be noted that the Portugal General-Directorate for Health considers an elderly person to be 65 years of age or older [19].

\section{Dependent Variables}

The variables related to food consumption were recoded as dichotomous variables ("yes" or "no" for consumption in the day before the survey). The variables related to food consumption were the following: those included in the "Mediterranean diet" [20] (soup, whole grain or beans, fish, natural juices made from fresh fruit, bread, rice, pasta, and potatoes), and those that are not in the Mediterranean diet (meat, dairy products [milk, cheese, and yogurt], cakes, fast food, precooked meals, refrigerants with or without gas, chocolates, and desserts).

In the NHIS, fast food was described as a "meal prepared and served quickly according to a standardized and massed method, whether or not it is consumed at the place of purchase" and a precooked meal was described as a meal prepared "according to an industrialized method which comprises partially or completely cooking the same, preserving it according to cooling, freezing, vacuuming or canning processes, and that before being consumed requires the finalization of the confection by means of heat treatment such as oven, microwave or frying" [17].

Variables related to the frequency of fruit and vegetable consumption included salads and juices made from fresh and canned vegetables and vegetarian dishes (but excluded juices prepared from concentrates). The question referred to usual habits, i.e., "how many fruits/vegetables do you usually consume per day?". These 2 variables were also recoded as dichotomous variables ("fewer than 3 servings per day" and " 3 or more servings per day"). This option was based on the recommendation of the official Portuguese Wheel of Food, which recommends a daily consumption of 3-5 servings of fruit and vegetables per day [21].

\section{Explanatory Variables}

The education variable refers to the highest level of education that the individual has completed or obtained equivalence of; this
Table 2. Food consumption among women and men

\begin{tabular}{lcc}
\hline & Women, $n(\%)$ & Men, $n(\%)$ \\
\hline Dairy products & $5,191(86.1)$ & $4,073(81.1)$ \\
Soup & $3,733(61.9)$ & $2,901(57.8)$ \\
Bread & $5,446(90.4)$ & $4,699(93.5)$ \\
Meat & $4,524(75.1)$ & $4,188(83.4)$ \\
Fish & $2,786(46.2)$ & $2,337(46.5)$ \\
Potato, rice, and pasta & $5,172(85.8)$ & $4,555(90.7)$ \\
Legumes & $1,633(27.1)$ & $1,572(31.3)$ \\
Cakes, chocolate, and desserts & $2,321(38.5)$ & $1,955(39.7)$ \\
Soft drinks & $1,806(30)$ & $1,923(38.3)$ \\
Natural fruit juices & $752(12.5)$ & $564(11.2)$ \\
Fast food & $230(3.8)$ & $201(4.0)$ \\
Precooked meals & $227(3.8)$ & $194(3.9)$ \\
Fruit portions $(\geq 3 /$ day) & $1,623(36.3)$ & $1,096(32.7)$ \\
Vegetable portions $(\geq 3 /$ day $)$ & $645(17.9)$ & $348(15.3)$ \\
\end{tabular}

was recoded into the following categories: preschool or none, basic education, secondary education, and college education.

The income variable establishes the net monthly income, after deduction of taxes, social security contributions, and voluntary contributions, per equivalent adult, including income on a regular basis. The variable was divided into quintiles in the database that was assigned to us, for confidentiality reasons. Note that the first quintile refers to the lowest-income persons and the fifth quintile to the most affluent ones.

\section{Covariables}

Age and sex represent the covariables of this study. Age was categorized into the following 4 groups: $25-34,35-44,45-54$, and 55-64 years and the sex variable was already defined as a dichotomous variable, i.e., female and male. Note that the age categories were defined in the database we received, without access to the exact age as continuous, for confidentiality reasons.

\section{Statistical Analysis}

A brief description of the sample was made regarding sex, age group, and level of education.

Multivariate logistic regression models were used to estimate the magnitude of associations between consumption of different food items and education and income through OR measures. Logistic regression models were then stratified for men and women and for age groups (younger vs. older than 45 years). Separate regressions were performed for each explanatory variable (education and income), adjusted for age. $p<0.05$ was considered statistically significant. The analyses were performed using SPSS 22.0 statistical analysis software.

\section{Results}

This study included 11,085 individuals, i.e., 5,037 men (45.4\%) and 6,048 women (54.6\%). The majority had basic education $(52.7 \%$ among women and $61.3 \%$ among 
Table 3. OR for food consumption according to the age-adjusted educational level for men and women

\begin{tabular}{|c|c|c|c|c|c|c|}
\hline \multirow[t]{3}{*}{ Food category } & \multicolumn{6}{|c|}{ Educational level (college $=$ reference category) } \\
\hline & \multicolumn{3}{|l|}{ women } & \multicolumn{3}{|l|}{ men } \\
\hline & $\begin{array}{l}\text { preschool } \\
\text { or none }\end{array}$ & $\begin{array}{l}\text { basic } \\
\text { education }\end{array}$ & $\begin{array}{l}\text { secondary } \\
\text { education }\end{array}$ & $\begin{array}{l}\text { preschool } \\
\text { or none }\end{array}$ & $\begin{array}{l}\text { basic } \\
\text { education }\end{array}$ & $\begin{array}{l}\text { secondary } \\
\text { education }\end{array}$ \\
\hline Dairy products & 0.212 & 0.607 & 0.889 & 0.246 & 0.493 & 0.850 \\
\hline Soup & 0.820 & 0.723 & 0.883 & 0.685 & 0.609 & 0.767 \\
\hline Bread & 1.122 & 0.984 & 0.953 & 1.562 & 1.740 & 1.107 \\
\hline Meat & 0.868 & 1.091 & 1.097 & 0.572 & 0.944 & 1.194 \\
\hline Fish & 0.480 & 0.670 & 0.757 & 0.570 & 0.598 & 0.735 \\
\hline Potatoe, rice, and pasta & 1.034 & 1.117 & 1.028 & 0.712 & 0.825 & 0.876 \\
\hline Legumes & 1.412 & 1.209 & 0.902 & 1.456 & 1.418 & 1.426 \\
\hline Cakes, chocolate, and dessert & 0.510 & 0.758 & 0.956 & 0.481 & 0.670 & 0.918 \\
\hline Soft drinks & 3.482 & 2.374 & 1.443 & 2.443 & 1.973 & 1.525 \\
\hline Natural fruit juices & 0.270 & 0.423 & 0.647 & 0.181 & 0.376 & 0.637 \\
\hline Fast food & 0.926 & 0.588 & 0.805 & 0.285 & 0.705 & 1.036 \\
\hline Precooked meals & 0.585 & 0.832 & 0.918 & 0.391 & 0.631 & 1.121 \\
\hline $\begin{array}{l}\text { Fruit consumption } \\
\geq 3 \text { servings/day }\end{array}$ & 0.464 & 0.633 & 0.854 & 0.608 & 1.106 & 1.054 \\
\hline $\begin{array}{l}\text { Vegetable consumption } \\
\geq 3 \text { servings/day }\end{array}$ & 0.361 & 0.590 & 0.802 & 0.554 & 0.800 & 0.827 \\
\hline
\end{tabular}

Values in bold are statistically different from 1, for a threshold of 5\%.

men), but college education was more prevalent in women ( 24.3 vs. $16.5 \%$; Table 1 ).

Regarding food consumption, there were no substantial differences between men and women in the percentage of consumption of different foods (Table 2). However, consumption of dairy products, soup, and natural juices made from fresh fruit was reported more among women, as was daily consumption of 3 or more portions of fruit and vegetables.

For multivariate analysis we considered a gradient when we observed at least 2 categories with statistically significant results and increasing OR.

Among women the likelihood of consumption of dairy, fish, cakes, natural juices, and fruits and vegetables increased gradually with education (Table 3 ), while the probability of consumption of legumes and soft drinks decreased with a higher education. With regard to income, a positive gradient was observed only for fast food, fruits, and vegetables (Table 4) but the consumption of dairy products, soup, fish, cakes, and natural juices was lower among lower-income groups.

Among men the likelihood of consuming dairy, fish, cakes, and natural juices was greater with increasing levels of education (Table 3). Similar gradients were observed for income, including in the case of soup (Table 4).
The probability of consumption of legumes and soft drinks was lower among high-education and income categories. Contrary to women, the consumption of meat and precooked foods was lower among the lowest education and income groups.

Among young people the likelihood of consumption of dairy, fish, and natural juices, increased gradually with education (Table 5). On the contrary, the probability of consumption of legumes and soft drinks decreased with a higher education. With regard to income, a positive gradient was observed for dairy, soup, and fish, and an inverse gradient was found for legumes and soft drinks (Table 6).

Among older people the likelihood of consumption of dairy, fish, cakes, natural juices, precooked meals, fruits, and vegetables increased gradually with education (Table 5). Also, the likelihood of consumption of dairy, cakes, natural juices, fruits, and vegetables increased gradually with income (Table 6). On the contrary, the probability of consumption of legumes and soft drinks decreased with a higher education. Bread and soft drinks were more likely to be consumed among low-income groups. 
Table 4. OR for food consumption according to the age-adjusted income quintile for men and women

\begin{tabular}{|c|c|c|c|c|c|c|c|c|}
\hline \multirow[t]{3}{*}{ Food category } & \multicolumn{8}{|c|}{ Income quintile (quintile 5 = reference category) } \\
\hline & \multicolumn{4}{|l|}{ women } & \multicolumn{4}{|l|}{ men } \\
\hline & 1 (lowest) & 2 & 3 & 4 & 1 (lowest) & 2 & 3 & 4 \\
\hline Dairy products & 0.501 & 0.894 & 0.903 & 1.081 & 0.372 & 0.480 & 0.698 & 0.964 \\
\hline Soup & 0.754 & 0.838 & 0.810 & 0.868 & 0.752 & 0.798 & 0.810 & 0.847 \\
\hline Bread & 1.118 & 1.232 & 1.214 & 1.188 & 1.469 & 1.562 & 1.544 & 1.319 \\
\hline Meat & 0.991 & 1.072 & 1.074 & 1.068 & 0.745 & 0.932 & 1.031 & 1.030 \\
\hline Fish & 0.649 & 0.802 & 0.746 & 0.704 & 0.556 & 0.696 & 0.758 & 0.849 \\
\hline Potatoe, rice, and pasta & 1.275 & 1.329 & 1.191 & 1.223 & 0.681 & 1.223 & 0.980 & 1.011 \\
\hline Legumes & 1.411 & 1.233 & 1.157 & 0.996 & 1.200 & 1.292 & 1.301 & 1.173 \\
\hline Cakes, chocolate, and dessert & 0.713 & 0.712 & 0.893 & 0.858 & 0.547 & 0.697 & 0.730 & 0.872 \\
\hline Soft drinks & 2.398 & 1.929 & 1.988 & 1.643 & 1.662 & 1.513 & 1.575 & 1.358 \\
\hline Natural fruit juices & 0.495 & 0.449 & 0.501 & 0.613 & 0.405 & 0.412 & 0.606 & 0.511 \\
\hline Fast food & 0.568 & 0.601 & 0.734 & 1.142 & 0.714 & 0.950 & 0.857 & 1.111 \\
\hline Precooked meals & 0.915 & 0.812 & 1.016 & 1.252 & 0.586 & 0.637 & 0.898 & 0.933 \\
\hline $\begin{array}{l}\text { Fruit consumption } \\
\geq 3 \text { servings/day }\end{array}$ & 0.587 & 0.684 & 0.713 & 0.725 & 0.872 & 0.865 & 0.892 & 1.011 \\
\hline $\begin{array}{l}\text { Vegetable consumption } \\
\geq 3 \text { servings/day }\end{array}$ & 0.590 & 0.634 & 0.697 & 0.652 & 0.617 & 0.986 & 0.824 & 0.943 \\
\hline
\end{tabular}

Values in bold are statistically different from 1, for a threshold of 5\%.

Table 5. OR for food consumption according to the age-adjusted educational level for younger and older people

\begin{tabular}{|c|c|c|c|c|c|c|}
\hline \multirow[t]{3}{*}{ Food category } & \multicolumn{6}{|c|}{ Educational level (college $=$ reference category) } \\
\hline & \multicolumn{3}{|c|}{ age $<45$ yearsd } & \multicolumn{3}{|c|}{ age 45 years or older } \\
\hline & $\begin{array}{l}\text { preschool } \\
\text { or none }\end{array}$ & $\begin{array}{l}\text { basic } \\
\text { education }\end{array}$ & $\begin{array}{l}\text { secondary } \\
\text { education }\end{array}$ & $\begin{array}{l}\text { preschool } \\
\text { or none }\end{array}$ & $\begin{array}{l}\text { basic } \\
\text { education }\end{array}$ & $\begin{array}{l}\text { secondary } \\
\text { education }\end{array}$ \\
\hline Dairy products & 0.214 & 0.584 & 0.850 & 0.228 & 0.524 & 0.932 \\
\hline Soup & 0.906 & 0.669 & 0.809 & 0.815 & 0.727 & 0.887 \\
\hline Bread & 1.297 & 1.226 & 0.897 & 1.494 & 1.330 & 1.270 \\
\hline Meat & 0.679 & 0.988 & 1.143 & 0.698 & 1.030 & 1.127 \\
\hline Fish & 0.379 & 0.597 & 0.725 & 0.644 & 0.724 & 0.792 \\
\hline Potatoe, rice, and pasta & 0.606 & 0.926 & 0.876 & 1.040 & 1.104 & 1.173 \\
\hline Legumes & 1.688 & 1.350 & 1.012 & 1.327 & 1.240 & 1.246 \\
\hline Cakes, chocolate, and dessert & 0.663 & 0.737 & 0.882 & 0.448 & 0.700 & 1.083 \\
\hline Soft drinks & 2.052 & 2.196 & 1.434 & 3.005 & 2.004 & 1.651 \\
\hline Natural fruit juices & 0.250 & 0.545 & 0.648 & 0.195 & 0.306 & 0.646 \\
\hline Fast food & 1.009 & 0.563 & 0.850 & 0.238 & 0.741 & 1.160 \\
\hline Precooked meals & 0.865 & 0.745 & 1.042 & 0.262 & 0.650 & 0.963 \\
\hline $\begin{array}{l}\text { Fruit consumption } \\
\quad \geq 3 \text { servings/day }\end{array}$ & 0.562 & 0.915 & 0.913 & 0.490 & 0.728 & 0.900 \\
\hline $\begin{array}{l}\text { Vegetable consumption } \\
\geq 3 \text { servings/day }\end{array}$ & 0.190 & 0.786 & 0.844 & 0.433 & 0.572 & 0.751 \\
\hline
\end{tabular}

Values in bold are statistically different from 1, for a threshold of 5\%. 
Table 6. OR for food consumption according to the age-adjusted income quintile for younger and older people

\begin{tabular}{|c|c|c|c|c|c|c|c|c|}
\hline \multirow[t]{3}{*}{ Food category } & \multicolumn{8}{|c|}{ Income quintile (quintile 5 = reference category) } \\
\hline & \multicolumn{4}{|c|}{ age $<45$ years } & \multicolumn{4}{|c|}{ age $>45$ years or older } \\
\hline & 1 (lowest) & 2 & 3 & 4 & 1 (lowest) & 2 & 3 & 4 \\
\hline Dairy products & 0.400 & 0.603 & 0.675 & 0.977 & 0.451 & 0.675 & 0.881 & 1.044 \\
\hline Soup & 0.715 & 0.733 & 0.767 & 0.828 & 0.770 & 0.887 & 0.834 & 0.862 \\
\hline Bread & 1.081 & 1.091 & 1.183 & 1.156 & 1.343 & 1.654 & 1.460 & 1.260 \\
\hline Meat & 0.852 & 1.013 & 0.964 & 1.079 & 0.924 & 1.022 & 1.137 & 1.042 \\
\hline Fish & 0.647 & 0.697 & 0.730 & 0.748 & 0.575 & 0.788 & 0.754 & 0.770 \\
\hline Potatoe, rice, and pasta & 0.885 & 1.091 & 1.016 & 1.055 & 1.100 & 1.413 & 1.177 & 1.204 \\
\hline Legumes & 1.518 & 1.272 & 1.259 & 1.027 & 1.189 & 1.236 & 1.183 & 1.115 \\
\hline Cakes, chocolate, and dessert & 0.816 & 0.810 & 0.897 & 0.923 & 0.529 & 0.627 & 0.756 & 0.828 \\
\hline Soft drinks & 2.390 & 1.890 & 1.775 & 1.582 & 1.759 & 1.534 & 1.770 & 1.421 \\
\hline Natural fruit juices & 0.662 & 0.536 & 0.651 & 0.716 & 0.331 & 0.358 & 0.465 & 0.451 \\
\hline Fast food & 0.726 & 0.704 & 0.817 & 1.201 & 0.540 & 0.886 & 0.832 & 1.125 \\
\hline Precooked meals & 0.808 & 0.889 & 1.050 & 1.430 & 0.674 & 0.520 & 0.833 & 0.642 \\
\hline $\begin{array}{l}\text { Fruit consumption } \\
\geq 3 \text { servings/day }\end{array}$ & 0.948 & 0.969 & 0.869 & 0.897 & 0.572 & 0.648 & 0.729 & 0.793 \\
\hline $\begin{array}{l}\text { Vegetable consumption } \\
\geq 3 \text { servings/day }\end{array}$ & 0.695 & 0.960 & 0.878 & 0.803 & 0.551 & 0.605 & 0.694 & 0.721 \\
\hline
\end{tabular}

Values in bold are statistically different from 1, for a threshold of 5\%.

\section{Discussion/Conclusion}

\section{Main Results}

A positive and significant gradient with education and income was observed across all demographic groups for dairy products, fish, cakes, and natural juices. An inverse significant gradient with education and income was observed across all demographic groups for soft drinks and legumes. The socioeconomic gradient for fruits and vegetables was observed only among women and the elderly. Worse-off persons consumed less soup, and underprivileged women consumed fewer fast food products.

Education gradients were more present among women, while income gradients were more common among men. We also observed more education and income gradients among older people compared to younger ones.

\section{Interpretation}

The results of this study contrast with what was observed in a national study also conducted on the basis of the NHIS (1998-1999), which found that education was more often associated with food choices than income [11]. In light of this work, income is also linked to the food consumption of Portuguese adults. Perhaps the economic and financial crisis that began in 2008 in Portugal has increased economic inequalities, resulting in an increase in precariousness and poverty and poorer access to certain foods [22]. There is evidence that the higher cost of more nutritious foods explains their lower consumption by economically disadvantaged groups [23], so income inequality is theoretically plausible.

Let us detail the various observed associations. First, the results show that fish consumption is more likely among those with higher levels of education and income, in line with several studies [24]. The association between socioeconomic status and fish consumption was also a reality for the income variable. In addition to the fact that education may reflect income, the literature also indicates that the higher cost of this food may constitute a barrier to its consumption by the poor [24] and this food is considered a luxury item [25]. Also, education reflects a better knowledge of food composition, nutritional components, and their link to health.

Second, the consumption of cakes, chocolate, and desserts was more likely among those with a higher income and education, between men and women. A recent study showed that, although more educated individuals opt for snacks that include pieces of fruit, they are also more likely to eat cakes in these same mid-range meals compared to individuals with a lower education [26]. However, the literature suggests the opposite for income; lower-income individuals consume more and spend more on foods with 
a high energy density, i.e., rich in sugar and fat, explained by the lower costs of these foods when compared to foods of a high nutritional density [27]. A negative relationship between energy density, i.e., the quantity of calories, and the cost of food has actually been established [28]. However, studies on this subject suggest the existence of a nonlinear relationship between income and consumption of foods rich in added sugars, with a reduction in consumption as income increases to a certain value and an increase in consumption thereafter as income continues to rise [29]. This nonlinear relationship may explain the positive relationship. Our results may also be justified by underprivileged people being deprived of meeting their basic needs, including their choice of less healthy options such as desserts, cakes, and chocolate [30]. Also, there is a possibility that low-income people consume foods with higher processing and higher added sugars, while those with a higher income may opt for home-made desserts with no added or low added sugars. A similar explanation may hold for the lower consumption of fresh juices among the worse off. However, this interpretation has not yet been evaluated in the literature. There is evidence in the USA, for example, of a higher consumption of ultraprocessed foods in socially vulnerable populations [31].

Third, the consumption of legumes in Portugal was higher among individuals with a lower socioeconomic status. The contrary was expected, given that better-off people have more nutritional knowledge and thus knowledge about the benefits of these foods. However, the fact that they are low-cost foods may be the explanation for their more frequent consumption among low-income people. Similar results were found for southern European countries (not including Portugal), explained by the lower cost and the culturally generalized consumption of legumes [32].

Fourth, women and men with lower levels of education and income were more likely to consume soft drinks. The literature also verified that individuals with a lower income and education are more likely to consume gas or noncarbonated soft drinks, probably because of the greater susceptibility to marketing $[33,34]$. The level of education is considered a determinant in the consumption of these beverages, since it is related to the level of health literacy. The literature demonstrates that those with a lower level of health education consume $119 \mathrm{kcal}$ more per day from carbonated and noncarbonated beverages than individuals with a higher level of health education [35].

Fifth, fruit and vegetable consumption was more likely among women and older people with a higher educa- tion and a higher income, in agreement with the literature [36]. Since fruits and vegetables are the food products that contribute most to food expenditures, their consumption is reduced when the income is low $[36,37]$. However, the price may not be the only explanation for this outcome, since dietary improvements may be possible without high costs; in 2008, an American adult with an energy intake of 2,000 kcal/day could achieve the recommendations for fruits and vegetables (according to the Dietary Guidelines for Americans in 2019) for USD 2-2.50 per day ( EUR 1.70-2.15) [38]. Thus, the level of education may reflect other aspects such as nutritional knowledge and the ability to interpret information about health education [39]. Additionally, more affluent and educated people may live in neighborhoods where such products are more easily available $[40,41]$. The weaker or absent relationship among men and younger people may be related to their overall lower consumption of these products [42], which may be related to cultural reasons transversal to socioeconomic groups.

Two cases for which no clear gradient was found deserve further explanation. First, worse-off people exhibited a lower consumption of soup in all groups. Despite the scarcity of information about soup consumption among Portuguese individuals and their association with socioeconomic status, Moreira and Padrão [11] also found that consumption of vegetable soup was more likely among those with a higher level of education. The fact that the educational differences are stronger among men may be related to the fact that men with lower levels of education have a more negative attitude toward the consumption of vegetables, while men with higher levels of education have more interest in healthy eating [43].

Second, in relation to fast food consumption, statistically significant differences were found only among women. These results show partial agreement with some studies that report a higher consumption among those with higher levels of income [44]. This association may be explained by the time constraint associated with extraordinary working hours among higher-income women, which limits their ability to prepare meals at home [45]. Recent evidence also shows that low-educated women spend more time cooking than high-educated women, while the contrary holds for men [46].

\section{Limitations and Strengths}

First, the data did not allow us to measure the quantity/ portions of food that had been consumed, nor was it possible to translate food products into calories and nutri- 
ents. As a result, we could not identify those who consume foods with a higher energy or nutritional density.

The quality of the food is not mentioned. It is not reported whether the dairy products have a low, medium, or high fat content; whether the meat to which individuals refer is mostly red or white meat; or whether the consumption of cakes, chocolate, and desserts includes home-made desserts, with no or low added sugars, or just processed foods. This is why we did not categorize the food items as "healthy" or "unhealthy" and did not include them within specific diet patterns, such as the Mediterranean one.

In addition, the food consumption reports refer to the previous day, i.e., the previous $24 \mathrm{~h}$. The use of this method of assessing food intake may result in a memory bias. In addition, this method does not estimate the habitual intake, and the reported intake may be atypical. A better method to evaluate food consumption would be a food diary, as it does not depend on memory and measures current consumption. However, it was decided to use this database given its availability, large number of participants, representativeness of the Portuguese population, and information on socioeconomic status. Moreover, there is no evidence of a greater potential bias in specific socioeconomic groups, so inequality values are not expected to be biased.

This work is the most recent study on this subject in Portugal that is based on a representative and recent sample of the Portuguese population, and this can be pointed to as one of its strengths. In addition, data from several foods are analyzed, which reveals the eating patterns of Portuguese adults. Finally, 2 indicators and variables of the socioeconomic status (income and education) were used and analyzed, which allows us to reduce the bias of results given by a single variable, with a separate study of male and female subjects.

\section{Implications}

According to the present study, it seems plausible that the price of food represents a barrier to the adoption of healthier food choices for the most disadvantaged. The literature indicates that fiscal policies involving taxes and subsidies have a greater impact among those with a lower income and a lower level of education. Thus, the use of economic incentives has been studied to reduce inequalities in food consumption, and the implementation of fiscal policies on food has been recommended by the World Health Organization in order to encourage a healthier diet [47].

These fiscal policies are based on the principle that the demand for high-salt, high-fat, and high-sugar foods is normally elastic, with a price elasticity between -0.9 and -1.3 . In addition, this elasticity is greater among low-income consumers [47]. Thus, regressivity is expected to be one of the effects of this type of taxation and, therefore, those with a lower income are subject to greater changes in their consumption. Although it can be argued that in fiscal terms these rates are unjust because they fall on the poorest, they will promote health equity, dissuading those with a lower income from consuming less healthy foods [48].

Note that nutritional education and health education strategies also have the potential to reduce inequalities in food consumption, though in a different way. According to a simulation based on data from one region of The Netherlands, nutritional education strategies focused on all socioeconomic groups could reduce inequality by $14.9-15.4 \%$, but strategies focused on lower-income groups may reduce it by only $12.2-14.1 \%[49,50]$. Strategies focused on health education may include nutritional counselling and distribution of teaching materials providing information on labeling and nutrition benefits and harms. The literature also states that the most successful strategies may be those focused on women, since they are often responsible for the preparation and acquisition of food [51].

\section{Conclusion}

In Portugal, regardless of sex, individuals with a higher income and a higher education are more likely to consume healthier foods, i.e., fish, fruits and vegetables, and natural juices made from fresh fruit.

Thus, policies to encourage healthy eating in the population should also focus on inequality in food, promoting better nutrition in socially vulnerable groups.

\section{Statement of Ethics}

The authors have no ethical conflicts to disclose.

\section{Conflict of Interest Statement}

The authors have no conflict of interests to declare.

\section{Author Contributions}

This study was performed as part of the master thesis of A.R.V. A.R.V. performed the literature review and the data analysis, interpreted the results, and drafted this paper. J.P. contributed to the study design and result interpretation and revised this paper. Both authors read and approved the final version of this work.
18

Port J Public Health 2021;39:11-20 DOI: $10.1159 / 000515937$
Velhinho/Perelman 


\section{References}

1 World Health Organization. Global status report on noncommunicable diseases 2014 . Geneva: WHO; 2014.

2 Sommer I, Griebler U, Mahlknecht P, Thaler K, Bouskill K, Gartlehner G, et al. Socioeconomic inequalities in non-communicable diseases and their risk factors: an overview of systematic reviews. BMC Public Health. 2015 Sep;15(1):914.

3 Mackenbach JP, Stirbu I, Roskam AJ, Schaap MM, Menvielle G, Leinsalu M, et al.; European Union Working Group on Socioeconomic Inequalities in Health. Socioeconomic inequalities in health in 22 European countries. N Engl J Med. 2008 Jun;358(23):246881.

4 Campos-Matos I, Russo G, Perelman J. Connecting the dots on health inequalities-a systematic review on the social determinants of health in Portugal. Int J Equity Health. 2016 Feb;15(1):26.

5 Méjean C, Droomers M, van der Schouw YT, Sluijs I, Czernichow S, Grobbee DE, et al. The contribution of diet and lifestyle to socioeconomic inequalities in cardiovascular morbidity and mortality. Int J Cardiol. 2013 Oct; 168(6):5190-5.

6 Petrovic D, de Mestral C, Bochud M, Bartley M, Kivimäki M, Vineis P, et al. The contribution of health behaviors to socioeconomic inequalities in health: A systematic review. Prev Med. 2018 Aug;113:15-31.

7 Black C, Moon G, Baird J. Dietary inequalities: what is the evidence for the effect of the neighbourhood food environment? Health Place. 2014 May;27:229-42.

8 Martikainen P, Brunner E, Marmot M. Socioeconomic differences in dietary patterns among middle-aged men and women. Soc Sci Med. 2003 Apr;56(7):1397-410.

9 Murray CJ, Aravkin AY, Zheng P, Abbafati C, Abbas KM, Abbasi-Kangevari M, et al.; GBD 2019 Risk Factors Collaborators Global burden of 87 risk factors in 204 countries and territories, 1990-2019: a systematic analysis for the Global Burden of Disease Study 2019. Lancet. 2020 Oct;396(10258): 1223-49.

10 Lopes C, Torres D, Oliveira A, Severo M, Alarcão V, Guiomar S, et al. National Food, Nutrition, and Physical Activity Survey of the Portuguese General Population 2015-2016: summary of results. Porto: University of Porto; 2018.

11 Moreira PA, Padrão PD. Educational and economic determinants of food intake in Portuguese adults: a cross-sectional survey. BMC Public Health. 2004 Dec;4(1):58

12 Gregório MJ, Graça P, Costa A, Nogueira PJ. Time and regional perspectives of food insecurity during the economic crisis in Portugal, 2011-2013. Saude Soc. 2014;23(4):1127-41.

13 Alves L, Azevedo A, Silva S, Barros H. Socioeconomic inequalities in the prevalence of nine established cardiovascular risk factors in a southern European population. PLoS One. 2012;7(5):e37158.

14 Vilela S, Muresan I, Correia D, Severo M, Lopes $\mathrm{C}$. The role of socio-economic factors in food consumption of Portuguese children and adolescents: results from the National Food, Nutrition and Physical Activity Survey 20152016. Br J Nutr. 2020 Sep;124(6):591-601.

15 Kawachi I, Adler NE, Dow WH. Money, schooling, and health: mechanisms and causal evidence. Ann N Y Acad Sci. 2010 Feb; 1186(1):56-68.

16 Arganini C, Saba A, Comitato R, Virgili F, Turrini A. Gender differences in food choice and dietary intake in modern western societies. Public Heal Behav Heal. 2012;4:83-102.

17 Eurostat. European Health Interview Survey (EHIS wave 2): methodological manual. Luxembourg: Publications Office of the European Union; 2013.

18 Alves J, Kunst AE, Perelman J. Evolution of socioeconomic inequalities in smoking: results from the Portuguese national health interview surveys. BMC Public Health. 2015 Mar;15(1):311.

19 Ministério da Saúde Portugal. Programa Nacional para a Saúde das pessoas idosas. Lisbon: Direção-Geral da Saúde; 2006.

20 Sofi F, Cesari F, Abbate R, Gensini GF, Casini A. Adherence to Mediterranean diet and health status: meta-analysis. BMJ. 2008 Sep; 337:a1344.

21 Ministério da Saúde Portugal. A nova roda dos alimentos [Internet]. Lisbon: DireçãoGeral da Saúde; 2021 [cited 2021 Feb 22]. Available from: https://alimentacaosaudavel. dgs.pt/roda-dos-alimentos/.

22 Carmo RM, Cantante F. Desigualdades, redistribuição e o impacto do desemprego: tendências recentes e efeitos da crise económico-financeira. Sociol Probl e Práticas. 2015;(77):33-51.

23 Darmon N, Drewnowski A. Contribution of food prices and diet cost to socioeconomic disparities in diet quality and health: a systematic review and analysis. Nutr Rev. 2015 Oct; 73(10):643-60.

24 Jahns L, Raatz SK, Johnson LK, Kranz S, Silverstein JT, Picklo MJ Sr. Intake of seafood in the US varies by age, income, and education level but not by race-ethnicity. Nutrients. 2014 Dec;6(12):6060-75.

25 Green R, Cornelsen L, Dangour AD, Turner R, Shankar B, Mazzocchi M, et al. The effect of rising food prices on food consumption: systematic review with meta-regression. BMJ. 2013 Jun;346:f3703.

26 Myhre JB, Løken EB, Wandel M, Andersen LF. The contribution of snacks to dietary intake and their association with eating location among Norwegian adults - results from a cross-sectional dietary survey. BMC Public Health. 2015 Apr; 15(1):369.

27 Drewnowski A, Specter SE. Poverty and obesity: the role of energy density and energy costs. Am J Clin Nutr. 2004 Jan;79(1):6-16.
28 Drewnowski A, Darmon N. Food choices and diet costs: an economic analysis. J Nutr. 2005 Apr;135(4):900-4.

29 Haley S, Reed J, Lin BH, Cook A. Sweetener consumption in the United States: distribution by demographic and product characteristics. Washington: Economic Research Service US Department of Agriculture; 2005. p. $1-19$.

30 Ntouva A, Tsakos G, Watt RG. Sugars consumption in a low-income sample of British young people and adults. Br Dent J. 2013 Jul; 215(1):E2-2.

31 Baraldi LG, Martinez Steele E, Canella DS Monteiro CA. Consumption of ultra-processed foods and associated sociodemographic factors in the USA between 2007 and 2012: evidence from a nationally representative cross-sectional study. BMJ Open. 2018 Mar; 8(3):e020574.

32 Roos G, Johansson L, Kasmel A, Klumbiené J, Prättälä R. Disparities in vegetable and fruit consumption: european cases from the north to the south. Public Health Nutr. 2001 Feb; 4(1):35-43

33 Han E, Powell LM. Consumption patterns of sugar-sweetened beverages in the United States. J Acad Nutr Diet. 2013 Jan;113(1):4353.

34 Rehm CD, Peñalvo JL, Afshin A, Mozaffarian D. Dietary intake among US adults, 1999-2012. JAMA. 2016 Jun;315(23):254253.

35 Zoellner J, You W, Connell C, Smith-Ray RL, Allen K, Tucker KL, et al. Health literacy is associated with healthy eating index scores and sugar-sweetened beverage intake: findings from the rural Lower Mississippi Delta. J Am Diet Assoc. 2011 Jul; 111(7):1012-20.

36 Lallukka T, Pitkäniemi J, Rahkonen O, Roos E, Laaksonen M, Lahelma E. The association of income with fresh fruit and vegetable consumption at different levels of education. Eur J Clin Nutr. 2010 Mar;64(3):324-7.

37 Mackenbach JD, Brage S, Forouhi NG, Griffin SJ, Wareham NJ, Monsivais P. Does the importance of dietary costs for fruit and vegetable intake vary by socioeconomic position? $\mathrm{Br}$ J Nutr. 2015 Nov;114(9):1464-70.

38 Middaugh AL, Fisk PS, Brunt A, Rhee YS. Few associations between income and fruit and vegetable consumption. J Nutr Educ Behav. 2012 May-Jun;44(3):196-203.

39 Estaquio C, Druesne-Pecollo N, Latino-Martel P, Dauchet L, Hercberg S, Bertrais S. Socioeconomic differences in fruit and vegetable consumption among middle-aged French adults: adherence to the 5 A Day recommendation. J Am Diet Assoc. 2008 Dec;108(12): 2021-30

40 Ball K, Timperio A, Crawford D. Neighbourhood socioeconomic inequalities in food access and affordability. Health Place. 2009 Jun; 15(2):578-85. 
41 Duran AC, Diez Roux AV, Latorre MR, Jaime PC. Neighborhood socioeconomic characteristics and differences in the availability of healthy food stores and restaurants in Sao Paulo, Brazil. Health Place. 2013 Sep;23:3947.

42 Lee-Kwan SH, Moore LV, Blanck HM, Harris DM, Galuska D. Disparities in state-specific adult fruit and vegetable consumption, United States, 2015. MMWR Morb Mortal Wkly Rep. 2017 Nov;66(45):1241-7.

43 Roos G, Prättälä R, Koski K. Men, masculinity and food: interviews with Finnish carpenters and engineers. Appetite. 2001 Aug;37(1): 47-56.

44 Mohr P, Wilson C, Dunn K, Brindal E, Wittert G. Personal and lifestyle characteristics predictive of the consumption of fast foods in Australia. Public Health Nutr. 2007 Dec; 10(12):1456-63.
45 Turrell G, Giskes K. Socioeconomic disadvantage and the purchase of takeaway food: a multilevel analysis. Appetite. 2008 Jul;51(1): 69-81.

46 Taillie LS. Who's cooking? Trends in US home food preparation by gender, education, and race/ethnicity from 2003 to 2016. Nutr J. 2018 Apr;17(1):41.

47 World Health Organization. Fiscal policies for diet and prevention of noncommunicable diseases: technical meeting report, 5-6 May 2015. Geneva: WHO; 2016.

48 Thow AM, Downs S, Jan S. A systematic review of the effectiveness of food taxes and subsidies to improve diets: understanding the recent evidence. Nutr Rev. 2014 Sep;72(9): 551-65.
49 Blok DJ, de Vlas SJ, Bakker R, van Lenthe FJ. Reducing income inequalities in food consumption: explorations with an agent-based model. Am J Prev Med. 2015 Oct;49(4):60513.

50 Ko LK, Rodriguez E, Yoon J, Ravindran R, Copeland WK. A brief community-based nutrition education intervention combined with food baskets can increase fruit and vegetable consumption among low-income Latinos. J Nutr Educ Behav. 2016 Oct;48(9):609-17.e1.

51 Mayén AL, de Mestral C, Zamora G, Paccaud F, Marques-Vidal P, Bovet P, et al. Interventions promoting healthy eating as a tool for reducing social inequalities in diet in low-and middle-income countries: a systematic review. Int J Equity Health. 2016 Dec;15(1):205. 